\title{
KESELAMATAN TENAGA KERJA DALAM PERSPEKTIF HAK ASASI MANUSIA \\ (Perspektif Islam, UDHR, dan Hukum Positif)
}

\author{
Misranto; M. Taufik \\ Universitas Islam Malang \\ Jalan MT Haryono 193, Kota Malang \\ Email:mmisranto2@gmail.com; emtaufik415152@gmail.com
}

\begin{abstract}
ABSTRAK
Salah satu hak yang dimiliki oleh tenaga kerja adalah hak atas keselamatan. Hak atas keselamatan ini menjadi kewajiban yang harus dilaksanakan atau diimplementasikan oleh perusahaan. Perusahaan mempunyai kewajiban yang bersifat asasi untuk menegakkan kepentingan yang bersifat asasi pula. Sayangnya, kepentingan yang bersifar asasi ini kurang menjadi perhatian serius di kalangan pengusahaa atau perusahaan. Tidak sedikit ditemukan kasus-kasus pelanggaran terhadap hak tenaga kerja ini. Banyak tenaga kerja yang tidak mendapatkan perlindungan keselamatannya saat menjalankan kerjanya. Perusahaan yang demikian ini dapat dikategorikan melakukan pelanggaran terhadap hak asasi manusia.
\end{abstract}

Kata Kunci: Tenaga Kerja, Perusahaan, Hak atas Keselamatan

\begin{abstract}
One of the rights possessed by the workforce is the right to safety. The right to safety is an obligation that must be implemented or implemented by the company. Companies have a fundamental obligation to uphold basic interests as well. Unfortunately, these basic interests are less of a serious concern among entrepreneurs or companies. There are no few cases of violations of this labor rights. Many workers do not get safety protection when running their work. Such a company can be categorized as a violation of human rights.
\end{abstract}

Keywords: Labor, Company, Right to Safety

\section{PENDAHULUAN}

Ada fenomena memprihatinkan yang menimpa Tenaga Kerja Indonesia. Salah satu hak asasinya yang bernama hak atas keselamatan kerja masih sering dilanggar oleh perusahaan. Sejumlah perusahaan masih dikategorikan sebagai perusahaan yang tidak taat hukum atau masih tergolong melakukan pelanggaran terhadap hak tenaga kerja. Pelanggaran terhadap hak tenaga kerja ini seringkali disikapi bukan sebagai persoalan serius oleh negara atau perusahaan di level nasional atau masyarakat internasional.

Kementrian Tenaga Kerja dan Transmigrasi pernah merilis laporan, bahwa pelanggaran terhadap norma 
Keselamatan dan Kesehatan Kerja (K3) di diduga kuat ada pelanggaran Indonesia, masih terbilang cukup tinggi. Keselamatan dan Kesehatan Oleh karena itu, para pelaku industri Kerja. Terkait hal ini, Menaker telah diminta meningkatkan kepatuhan menginstruksikan kepada Dirjen terhadap norma K3. Berdasarkan data Pembinaan Pengawasan Ketenagakerjaan kemenakertrans, tercatat sebanyak 12.745 dan Keselamatan dan Kesehatan Kerja perusahaan melanggar norma K3. Dari (PPK dan K3) untuk melakukan jumlah itu, sebanyak 12.657 perusahaan pengusutan tuntas.

telah melaksanakan norma K3 pasca penerbitan nota peringatan pertama dan kedua. ${ }^{1}$ Pelanggaran ini terjadi pada era pemerintahan Presiden Susilo Bambang Yudoyono.

Di era pemerintahan Presiden Joko Widodo, pelanggaran terhadap hak atas keselamatan tenaga kerja juga masih saja terjadi. Misalnya Menteri Ketenagakerjaan, M. Hanif Dhakiri menginstruksikan kepada jajarannya untuk mengusut tuntas kasus kecelakaan kerja yang terjadi di gudang mercon milik PT Panca Buana Cahaya Sukses yang berlokasi di Desa Belimbing, Kabupaten Tangerang, Banten. Menurutnya kalau memperhatikan dahsyatnya kejadian, serta banyak korban meninggal dan luka karena tak dapat menyelamatkan diri, bertanggungjawab terhadap kasus ini. ${ }^{2}$

1 http://www.pikiranrakyat.com/ekonomi/2014/01/16/266259/1274 5-perusahaan-langgar-norma-keselamatankerja, akses 14 April 2018.
Melihat banyaknya korban serta temuan lapangan yang menunjukkan bahwa kondisi pintu gerbang pabrik yang selalu terkunci, diduga kuat perusahaan tersebut tidak memiliki Sistem Menejemen Keselamatan dan Kesehatan Kerja (SMK3) sebagaimana yang telah ditentukan oleh pemerintah. Salah satu ketentuan yang diatur dalam SMK3 adalah perusahaan harus mampu menanggulangi kebakaran, serta menyediakan akses jika terjadi kondisi kegawatdaruratan. Kepada para korban, pemerintah menjamin terlaksananya pemberian hak-hak korban. Baik hak bagi ahli waris pekerja yang meninggal, hak pengobatan bagi korban terluka serta hakhak lainnya. Perusahaan harus

2 http://poskotanews.com/2017/10/27/menakerada-pelanggaran-keselamatan-dan-kesehatankerja-di-pabrik-mercon/, akses 1 Mei 2018. 
Kasus tersebut setidaknya sebagai sampel bahwa pelanggaran terhadap hak keselamatan tenaga kerja Indonesia ini masih serius, artinya banyak perusahaan yang mengabaikan keselamatan tenaga kerjanya. Tenaga kerja yang semestinya mendapatkan perlindungan memadai justru terabaikan, sehingga mereka ditimpa kecelakaan atau kondisi tertentu yang membuat dirinya menjadi korban.

\section{PEMBAHASAN}

\section{Persektif UDHR}

Perlindungan terhadap tenaga kerja dimaksudkan untuk menjamin hak-hak dasar pekerja dan menjamin kesamaan serta perlakuan tanpa diskriminasi atas dasar apapun untuk mewujudkan kesejahteraan pekerja dan keluarganya dengan tetap memperhatikan perkembangan kemajuan dunia usaha dan kepentingan pengusaha. Perlindungan demikian diatur di berbagai ketentuan, ${ }^{3}$ termasuk diantaranya dalam instrumen-instrumen HAM untuk masyarakat internasional.

Di dalam Pasal 23 ayat 1,2, 3, dan 4 UDHR (Universal Declaration of Human
Rights) disebutkan: (1) Setiap orang berhak untuk memperoleh pekerjaan, bebas memilih pekerjaan, syarat-syarat yang adil, dan menyenangkan dari suatu lingkungan pekerjaan dan mendapat perlindungan dari pengangguran, (2) setiap orang tanpa dibeda-bedakan berhak memperoleh upah yang sama atas pekerjaan yang sama, (3) setiap orang yang bekerja berhak akan imbalan yang adil dan menyenangkan, yang menjamin dirinya sendiri dan keluarganya sesuai dengan kemuliaan martabat manusia dan ditambah pula bila perlu dengan bantuanbantuan sosial lainnya, dan (4) setiap orang berhak untuk membentuk dan bergabung dengan serikat-serikat pekerja untuk melindungi kepentingankepentingannya.

$\begin{array}{cccc}\text { Lingkungan } & \text { dan } & \text { kondisi } & \text { yang } \\ \text { menyenangkan } & \text { bagi } & \text { tenaga } & \text { kerja }\end{array}$
merupakan salah satu kebutuhan vitalnya. Tenaga kerja akan bisa menjalankan pekerjannya atau kewajibannya dengan baik jika didukung oleh lingkungan kerja yang baik pula. Ketika kondisi lingkungan pekerjaannya tidak menyenangkan,

Adisu, Editus \& Jehani, Lebertus (2007), HakHak Pekerja Perempuan, Tanggerang; VisiMedia, Hlm. 5. 
apalagi rawan dengan ancaman yang membahayakan kesehatan, apalagi keselamatannya, maka hal ini dapat dinilai sebagai kondisi yang yang tidak mendukung.

Fenomena di seputar ketenagakerjaan dewasa ini adalah masih banyaknya lingkungan kerja, termasuk di dalamnya manajemen kerja yang mengandung potensi kerawanan yang membahayakan atau menimbulkan berbagai bentuk kecelakaan kerja. Tidak sedikit perusahaan yang mempunyai manajemen kerja yang mengabaikan keselamatan kerja. Misalnya tenaga kerja meninggal dunia atau mengalami cacat kerja pada saat atau sedang menjalankan kewajibannya.

Kondisi ketenagakerjaan seringkali dikaitkan dengan kebijakan pembangunan atau tepatnya politik perekonomian secara nasional. Secara umum dijelaskan Teten Masduki, bahwa di bawah kebijakan politik dan ekonomi nasional, pertimbangan hak-hak buruh saat ini menghadapi persoalan yang sangat rumit. Bukan rahasia, buruh di tanah air ini

4 Nadj, E Shobirin dan Mardiniah, Naning, (2000), Diseminasi Hak Asasi Manusia, sangat rentan kehilangan pekerjaan dan sulit mendapatkan gantinya, menerima upah paling rendah di antara negaranegara tetangga, setiap dua hari seorang buruh tewas, dan senantiasa harus menghadapi tekanandan teror dari aparat keamanan. ${ }^{4}$

Kajian UDHR sudah menunjukkan, bahwa apapun perkembangan perekonomian nasional atau dunia, nasib tenaga kerja harus menjadi perhatian. Tenaga kerja mempunyai hak untuk dilindungi keselamatannya. Karena keselamatan ini merupakan modal istimewa bagi tenaga kerja untuk menjaga stabilitas perekonomian keluarga, masyarakat, bangsa, dan negara, termasuk perekonomian dunia.

\section{Perspektif Islam}

Di dalam Deklarasi OKI pasal 13 juga disebutkan, bahwa "bekerja adalah hal yang dijamin oleh pemerintah dan masyarakat untuk setiap orang yang siap untuk bekerja. Setiap orang harus bebas untuk memilih pekerjaan yang paling sesuai dan berguna bagi dirinya dan masyarakat".

Perspektif dan Aksi, Jakarta; Cesda-LP3ES. Hlm. 76. 
Di dalam Al-Qur'an juga disebutkan berhak untuk dijaga atau dilindungi oleh "Dan katakanlah: "bekerjalah kamu, maka perusahaan sebagaimana layaknya Allah dan RosulNya serta orang-orang perusahaan menjaga dan melindungi mukmin akan melihat pekerjaannya itu, kepentingannya, seperti keselamatan dan kamu akan dikembalikan kepada perusahaan.

(Allah) Yang Mengetahui akan yang ghaib dan nyata. Lalu diberitakanNya kepada kamu apa yang telah kamu kerjakan (QS At-Taubah: 105).

Di dalam Hadist disebutkan "berikanlah upah seorang buruh sebelum kering keringatnya, dan berikanlah upahnya sewaktu dia bekerja". (HR AlBayhaqi). Hadis ini menunjukkan perhatian yang cukup besar terhadap seseorang yang menjalankan kegiatan berupa "kerja". Dengan bekerja, seseorang diberi hak, yang salah satunya bernama "upah", yang kedudukan hukumnya adalah wajib untuk ditegakkan, dan bahkan penegakannya atau pelaksaannya tidak boleh ditunda-tunda.

Selain hak upah itu, tenaga kerja juga berhak atas hak lainnya, seperti hak perlindungan terhadap kesehatan dan keselamatan dirinya. Dijelaskan dalam suatu hadis yang berbunyi "berikanlah makan, minum, pakaian kepada buruhmu sebagaimana kamu kamu makan, minum dan berpakaian". Artinya, tenaga kerja
Jika ditafsirkan, kalau perusahaan itu punya orientasi tidak hanya sekedar makan, minum, dan pakaian, tetapi juga keselamatan usaha dan aset-asetnya, maka perusahaan juga punya kewajiban melindungi kesehatan dan keselamatan tenaga kerja. Melindungi kesehatan dan keselamatan tenaga kerja sama halnya dengan menjaga kesehatan dan keselamatan perusahaan.

Dalam Hadis lain juga disebutkan "pedagang yang jujur akan dihimpun pada hari kiamat bersama dengan orangorang yang benar dan suhada'. Hadis ini menunjukkan bahwa perusahaan wajib menunjukkan sikap kejujurannya dalam menjalin hubungan kerja dengan tenaga kerja yang menyangkut hak-hak tenaga kerja. Perusahaan tidak boleh membohongi atau berbuat curang terhadap hak-haknya.

Ketika dilakukan transaksi atau perjanjian kerja antara perusahaan dengan tenaga kerja, maka perusahaan berkewajiban menunjukkan hak-hak 
tenaga kerja dengan jujur. Kejujuran yang dilakukan perusahaan ini menjadi prinsip utama yang bisa menguatkan posisi tenaga kerja. Tenaga kerja akan terhambat dan bisa kehilangan hak-hak asasinya ketika perusahaan sering ketidakjujuran.

\section{Perspektif Yuridis Indonesia}

Dalam Pasal 28E Undang-Undang Dasar 1945 (Undang-Undang Dasar 1945 yang diamandemen) disebutkan, bahwa setiap orang bebas memeluk agama dan beribadat menurut agamanya, memilih pendidikan dan pengajaran, memilih pekerjaan, memilih kewarganegaraan, memilih tempat tinggal di wilayah negara dan meninggalkannya, serta berhak kembali.

Ketentuan konstitusi tersebut menunjukkan, bahwa salah satu HAM adalah hak untuk mencari, mendapatkan, dan memilih pekerjaan yang sesuai dengan keinginan atau barangkali bidang keilmuan dan ketrampilannya. Jenis pekerjaan merupakan salah satu aktivitas yang dapat memberikan manfaat secara ekonomi bagi seseorang. Melalui aspek ekonomi yang didapatkan dari pekerjaan yang dilakukannya ini, seseorang dapat meningkatkan taraf kehidupannya, seperti hak membebaskan diri dari kehidupan yang serba kesulitan menjadi kehidupan yang berkecukupan, dari kehidupan yang mengalami kemiskinan diperbaharui ke taraf kehidupan yang sejahtera.

Perlu dipahami, bahwa pengertian perjanjian kerja berdasarkan Pasal 1 Angka 14 Undang-Undang Nomor 13 tahun 2003 tentang Ketenagakerjaan, perjanjian kerja adalah perjanjian antara pekerja atau buruh dengan pengusaha atau pemberi kerja yang memuat syarat-syarat kerja, hak, dan kewajiban para pihak. Perlu diketahui terlebih dahulu bahwa ketentuan perjanjian kerja yang ada dalam Undang-Undang Nomor 13 tahun 2003 tentang Ketenagakerjaan merupakan bagian dari hubungan kerja atau ketenagakerjaan, bukan bagian dari hukum perjanjian, karena ketentuan perjanjian kerja bukan hukum pelengkap. Artinya ketentuan perjanjian kerja tidak dapat tidak diikuti, yaitu ketentuan perjanjian kerja dalam hukum 
ketenagakerjaan tersebut wajib ditaati dan dengan hilannya pekrjaan pula, atau diikuti. ${ }^{5}$

seseorang dapat terlempar ke jurang

Dalam ayat 1 pasal 1 Undang-Undang kemiskinan, dan bahkan kegiatanNomor 39 Tahun 1999 tentang Hak Asasi Manusia disebutkan, bahwa hak asasi kegiatan yang melanggar hukum dan norma agama.

manusia adalah seperangkat hak yang melekat pada hakikatnya dan keberadaan manusia sebagai makhluk Tuhan Yang Maha Esa dan merupakan anugerah-Nya yang wajib dihormati, dijunjung tinggi dan dilindungi oleh negara, hukum, Pemerintah, dan setiap orang demi kehormatan serta perlindungan ahrkat dan martabat manusia.

Dalam kedudukannya sebagai hak asasi itu, tentu saja setiap manusia Indonesia menjadi tergantung pekerjaan itu. Bahkan disebut pula, kalau salah satu tolok ukur kesuksesan seseorang dalam hidup ini, terutama dibidang ekonomi adalah terletak pada jenis pekerjaan apa yang sedang dijalankannya.

Secara filosofis yuridis dapat dipahami, bahwa hukum dibuat atau dibentuk untuk mengatur hak manusia untuk bekerj. Berawal dari pekerjaan, seseorang dapat menikmati kesejahteraan,
Begitu pula, bahwa berawal dari pekerjaan yang dapat membuahkan kekayaan banyak, seseorang bukan hanya dapat menjadi orang terpandang, tetapi juga dapat berbuat banyak untuk kepentingan daerah, lingkungan alam, dan sesama manusia yang membutuhkan manfaat dari pekerjaannya.

\section{Fokus Perlindungan Hak Tenaga Kerja}

Manusia memenuhi kebutuhan hidup untuk kelangsungan hidupnya di dunia. Untuk itu manusia perlu bekerja, sebab dengan bekerja manusia akan memanusiakan dirinya sebagai makhluk Allah yang paling sempurna dari seluruh ciptaan-Nya. Bekerja merupakan hak setiap manusia dewasa sebagai upaya menjaga derajat kemanusiaan dan memenuhi kebutuhan hidup. Negara dan masyarakat harus menjamin hak setiap manusia atau warga negara untuk bekerja
5 Rusli, Hardijan (2011), Hukum Ketenagakerjaan, Jakarta:, Ghalia Indonesia. HIm. 51. 
dan tidak membedakan hak tersebut antara satu dengan lainnya. ${ }^{6}$

Hal itu menunjukkan, bahwa dalam hidup ini manusia membutuhkan pekerjaan. Dengan pekerjaan yang dilaksanakan, manusia dapat memenuhi berbagai kebutuhan hidupnya. Sebab, dari pekerjaan yang dilakukan itu, manusia mendapatkan penghasilan. Sebagai hak manusia, maka pekerjaan dapat menentukan besarnya penghasilan. Sedangkan penghasilan ini juga menjadi hal yang harus dimilikinya setelah manusia menjalankan pekerjaan.

Begitu pentingnya bekerja atau pekerjaan bagi kehidupan manusia hingga kompetisi untuk memperebutkannya sangat ketat, bahkan tidak sedikit diantarannya yang terpaksa ditempuh dengan cara-cara yang melanggar normanorma agama dan hukum yang berlaku, seperti untuk mendapatkan pekerjaan, seseorang menempuhnya dengan cara menyuap atau menjual harga diri.

Vitalnya persoalan pekerjaan itu dapat dikaitkan dengan tanggungjawab pekerja yang tidak hanya untuk

6 Lopa, Baharuddin. (1996), Al-Qur'an dan Hak Asasi Manusia, Jakarta; Dhana Bhakti Prima Yasa, Hlm. 45.

pekerja yang tidak hanya untuk

kepentingan dirinya, tetapi juga untuk kepentingan atau kelangsungan hidup banyak pihak, seperti ada anak, isteri, dan orang lain yang menjadi tanggungjawabnya dan mengharapkan peran-perannya secara ekonomi. Karena kondisi inilah, maka hak atas keselamatan kerja menjadi demikian fundamental pentingnya.

Di dalam Universal Declaration of Human Rights (UDHR) atau Deklarasi Umum Hak Asasi Manusia pada prinsipnya menyebutkan bahwa setiap orang mempunyai hak untuk hidup, bebas, merdeka, dan keamanan pribadi. Deklarasi tersebut lahir sebagai acuan masyarakat internasional karena sebelumnya manusia hanya sebagai objek hukum rimba di tangan komunitas elit yang kuat. Masyarakat tidak ubahnya hanya raga-raga mati yang tidak bernyawa karena nasibnya ditentukan oleh raja, penguasa, atau kroni-kroni penguasa yang berpengaruh besar dalam melahirkan keputusan politik primordialisme sebagai hukum itu sendiri. 
Saat sebelum lahir deklarasi itu, Adalah tugas dari setiap individu, manusia atau rakyat tidak lebih dari masyarakat, dan negara untuk melindungi kumpulan pribadi yang terbelenggu oleh hak-hak ini dari setiap pelanggaran kekuatan kaum tiran. Mereka tidak punya apapun dan dilarang untuk mencabut kemerdekaan, tidak punya kebebasan kehidupan, kecuali dibenarkan oleh berbicara terbuka, dan tidak punya hak syari'at.

untuk beroposisi. Mereka dibuat tak berdaya oleh praktik kesombongan, kecongkakan, dan ketakaburan kekuasaan yang diabsolutkan. Mereka memang hidup, tapi esensinya mereka mengisi peti mati. Faktanya mereka bisa sewaktuwaktu dirampas jiwa dan nyawanya secara biadab oleh penguasa dan jaringannya.

Untuk mencegah "kebiadaban penguasa dan jaringannya" seperti pemilik modal, akhirnya masing-masing segmen bangsa di dunia yang merasa punya komitmen moral untuk merespon dan melindungi HAM, akhirnya dibuatkan kovenan semisal UDHR dengan maksud mulia: memartabatkan kehidupan manusia, menyelamatkan manusia dari berbagai bentuk perilaku yang bermodus “membinatangkannya"..

Pasal 2 (a) Cairo Declaration yang merupakan Deklarasi HAM Islam juga sejalan dengan UDHR tersebut, bahwa kehidupan adalah berkah Tuhan dan untuk hidup dijamin bagi setiap umat manusia.
Masing-masing negara yang telah menyetujui jadi negara penegak HAM dan hukum kemudian merumuskannya ke dalam hukum positipnya masing-masing. Hukum positip ini dimaksudkan untuk mengayomi, antara lain hak hidup rakyatnya dari berbagai bentuk perilaku yang membahayakan atau mengancam keselamatan, kesehatan dan kelangsungan hidupnya.

Produk hukum di bidang ketenagakerjaan yang dibuat juga untuk menjadi pijakan normative berupa perlindungan bagi keselamatan, kesehatan, dan keamanan kerja Kaum pekerja ini diberi pengayoman supaya ketika menjalankan kewajibannya di sector industri, pekerja dapat menjalakannya dengan maksimal. Jika pekerja mampu menunjukkan etos kerjanya dengan maksimal, maka niscaya produktifitasnya akan memenuhi target yang diinginkan oleh perusahaan. Jika perusahaannya memenuhi target, maka ini 
dapat menjadi indikasi pencerahan mengorbankan pekerja. Begitu pula ekonomi bangsa. ${ }^{7}$ misalnya ketika perusahaan sedang Sayangnya, seringkali hukum yang ditimpa musibah, itu disebabkan berbasis perlindungan hak (HAM) pekerja kesalahan atau kekhilafan manusianya. tidak ditegakkan. Menurut Fitzgerald, Ada apologi salah yang sering teori perlindungan hukum Salmond dikedepankan, bahwa dibalik alasan bahwa hukum bertujuan kesalahan manusia (human error) ini, mengintegrasikan dan sebenarnya perusahaan telah melakukan mengkoordinasikan berbagai kepentingan apa yang disebut pengabaian dan dalam masyarakat karena dalam suatu "kejahatan" dalam hal managemen lalulintas kepentingan, perlindungan perusahaan, yang potensinya berdampak terhadap kepentingan atau hajat tertentu dapat dilakukan dengan cara membatai berbagai kepentingan di lain pihak. ${ }^{8}$ Kepentingan hukum adalah mengurusi hak dan kepentingan manusia, sehingga hukum memiliki otoritas tertinggi atau istimewa untuk menentukan kepentingan manusia yang perlu diatur dan dilindungi. ${ }^{9}$

Dalam realitas, Perusahaan lebih senang memilih jalur yang tidak keselamatan kerja dapat diposisikan memanusiakan manusia dan melanggar sebagai korporasi yang melakukan hukum. Perusahaan gampang berdalih pelanggaran HAM. Perusahaan demikian kalau apa yang diperbuat, misalnya dalam itu dapat dikategorikan telah melakukan kasus rasionalisasi atau PHK, perusahaan pelanggaran HAM sebagaimana diatur diposisikan sedang terancam pailit dan dalam Pasal 1 ayat 6 Undang undang butuh diselamatkan dengan konsekuensi Nomor 39 tahun 1999 tentang HAM.

7 Rahmat, Fahmi, (2016), Quo Vadis Perlindungan Hak Tenaga Kerja, Jakarta; Muitara Ilmu, Hlm. 12. pada pelanggaran HAM. Ketuka aspek managemen ini diabaikan, mau tidak mau, nasib pekerjalah yang dipertaruhkan. Bagaimana mungkin kesehatan, keselamatan, dan keamanan kerjabisa dinikmati oleh pekerja, kalau perusahaan ternyata masih menjadikannya sebagai aspek yang sepele.

Perusahaan yang mengabaikan

8 Raharjo, Satijipto. Ilmu Hukum, Bandung; Citra Aditya Bakti. Hlm. 53.

$9 \quad$ Ibid. Hlm. 69. 
Pelanggaran hak asasi manusia adalah setiap perbuatan seseorang atau kelompok orang termasuk aparat negara baik sengaja ataupun tidak disengaja, atau kelalaian yang secara melawan hukum mengurangi, menghalangi, membatasi, atau mencabut hak asasi manusia seseorang atau kelompok orangyang dijamin oleh Undang-undang ini dan tidak mendapatkan atau dikhawatirkan tidak akan memperoleh penyelesaian hukum yang adil dan benar, berdasarkan mekanisme hukum yang berlaku.

Pekerja bukanlah sekedar modal untuk membesarkan kaum kapital, tetapi juga nafas bagi kehidupan republik ini. Jika mereka didera sakit-sakitan, tidak terjaga kesehatannya, apalagi sampai terampas nyawanya akibat pemilik modal atau perusahaan yang maniak keuntungan ekonomi tidak menegakkan hak keselamatannya, maka ini namanya perusahaan membenarkan pelanggaran HAM sebagai jalan tembus mengukuhkan kapitalisme, dan dimanapun namanya kapitalisme, tentulah butuh ongkos kebiadaban.

Meskipun kovenan yang mengatur perlindungan hak asasi manusia diberlakukan atau diimplementasikan, tetaplah tidak ada artinya atau bisa saja sekedar norma yang tertulis, bilamana ambisi keserakahan untuk mendapatkan keuntungan ekonomi berlipat ganda dilakukan dengan segala macam cara, termasuk mengabaikan atau mempermainkan hak keselamatan tenaga kerja. Perlakuan teerhadap tenaga kerja wajib dilakukan oleh perusahaan dengan cara memberikan perlindungan keselamatannya secara maksimal.

\section{PENUTUP}

Deskripsi terntang kondisi pengaturan dan beberapa fakta tentang perlindungan hak keselamatan tenaga kerja tersebut menunjukkan, bahwa dewasa ini masih menjadi suatu fenomena yang memprihatinkan mengenai lemahnya perlindungan terhadap tenaga kerja di bidang keselamatan kerja. Hak atas keselamatan kerja masih menjadi hak asasi yang belum sepenuhnya ditegakkan.

Dalam realitasnya, pemilik perusahaan masih memperlakukan pekerja sebagai obyek dan bukan sebagai subyek kerja. Perlakuan perusahaan terhadap pekerja belum menunjukkan perhatian yang serius. Terbukti tidak sedikit kecelakaan kerja di perusahaan-perusahaan yang 


\begin{abstract}
sebenarnya sudah memahami kewajibannya dalam melindungi keselamatan tenaga kerja atau memperlakukan tenaga kerjanya secara manusiawi.
\end{abstract}

\section{DAFTAR PUSTAKA Peraturan perundang-undangan}

Undang-Undang Dasar Negara Republik Indonesia.

Undang-undang Republik Indonesia Nomor 39 Tahun 1999 tentang Hak Asasi Manusia

Undang-undang Republik Indonesia Nomor 13 Tahun Tahun 2003 tentang Ketenagakerjaan.

Universsal Declaration of Human Rights

\section{Buku}

Baharuddin Lopa, 1996, Al-Qur'an dan Hak Asasi Manusia, Jkarta: Dhana Bhakti Prima Yasa.

Editus Adisu \& Lebertus Jehani, 2007, Hak-Hak Pekerja Perempuan, Tangerang: VisiMedia.
E Shobirin Nadj dan Naning Mardiniah, 2000, Diseminasi Hak Asasi Manusia, Perspektif dan Aksi, Jakarta: Cesda-LP3ES.

Hardijan Rusli, 2011, Hukum Ketenagakerjaan, Jakarta: Ghalia Indonesia.

Rahmat Fahmi, 2016, Quo Vadis Perlindungan Hak Tenaga Kerja, Jakarta: Muitara Ilmu.

Satijipto Raharjo, 2000, Ilmu Hukum, Bandung: Citra Aditya Bakti.

\section{Internet} ,http://www.pikiranrakyat.com/ekonomi/2014/01/16/266 259/12745-perusahaan-langgarnorma-keselamatan-kerja, akses 14 April 2018. ,http://poskotanews.com/2017 /10/27/menaker-ada-pelanggarankeselamatan-dan-kesehatan-kerja-dipabrik-mercon/, akses 1 Mei 2018. 